University of Nebraska - Lincoln

DigitalCommons@University of Nebraska - Lincoln

Faculty Papers and Publications in Animal

Science

Animal Science Department

$11-2008$

\title{
Fertility of semen used in commercial production and the impact of sperm numbers and bacterial counts
}

D. L. Reicks

Swine Veterinary Center, St. Peter, MN, dreicks@swinevetcenter.com

Donald G. Levis

University of Nebraska-Lincoln, donlevis@hotmail.com

Follow this and additional works at: https://digitalcommons.unl.edu/animalscifacpub

Part of the Animal Sciences Commons

Reicks, D. L. and Levis, Donald G., "Fertility of semen used in commercial production and the impact of sperm numbers and bacterial counts" (2008). Faculty Papers and Publications in Animal Science. 695. https://digitalcommons.unl.edu/animalscifacpub/695

This Article is brought to you for free and open access by the Animal Science Department at DigitalCommons@University of Nebraska - Lincoln. It has been accepted for inclusion in Faculty Papers and Publications in Animal Science by an authorized administrator of DigitalCommons@University of Nebraska - Lincoln. 
Published in Theriogenology 70:8 (November 2008), pp. 1377-1379; Proceedings of the VIth International Conference on Boar Semen Preservation; doi: 10.1016/j.theriogenology.2008.07.019 Copyright (C) 2008 Published by Elsevier Inc. Used by permission.

Published online September 2, 2008.

\title{
Fertility of semen used in commercial production and the impact of sperm numbers and bacterial counts
}

\author{
D. L. Reicks \\ Swine Veterinary Center, P.A., 1608 S. Minnesota Avenue, P.O. Box 269, St. Peter, MN 56082, USA; \\ Corresponding author - tel 507 931-3970; email dreicks@swinevetcenter.com \\ D. G. Levis \\ Animal Sciences Department, University of Nebraska-Lincoln, Lincoln, NE 68588 USA
}

\begin{abstract}
The objective was to monitor sperm counts and bacterial presence on randomly pooled semen doses over 3 years and to determine effects on the farrowing rate and total born in two large farm systems, each serviced by its own boar stud. Sperm counts were divided into increments of $0.5 \times 10^{9}$ for data analysis. There was no effect of sperm count or the presence of bacteria on farrowing rate ( $n=9502$ observations). Furthermore, based on 7311 observations, there was no effect of the mere presence of bacteria on total born, but sperm count had a significant effect on total born; in particular, total born decreased with pooled semen doses $<2.5 \times 10^{9}$ sperm.
\end{abstract}

Keywords: boar semen, artificial insemination, insemination dose, fertility, bacteria

\section{Introduction}

It is widely believed that extremely low sperm counts and the presence of bacteria affect fertility in swine. However, little work has been done in commercial production over an extended interval to address these issues. The first objective was to determine, over a 3-y interval, the total born and the farrowing rate of sows and gilts bred with individual pooled semen batches with known sperm quantity. The second objective was to determine the impact of the presence of bacteria when mating sows with these pooled semen batches.

\section{Materials and methods}

\subsection{Data inclusion}

Two boar studs each serving multiple sow farms collect semen $3 \mathrm{~d} / \mathrm{wk}$ and distribute it to farms the morning after collection. Semen was used on Days 1-4 af- ter collection. To be used for insemination, an ejaculate must have had a minimum of $70 \%$ motility, $70 \%$ normal morphology, and 70\% normal acrosomal ridge scores. Semen was used at random in two large production systems (30,000-40,000 sows). Each system has its own boar stud supplying the sow farms within the system. Four semen samples were submitted on each production day as part of the Swine Vet Center End Product Monitoring program. Sows and gilts mated with the same individual batch for each mating were included in the data analysis. Sows and gilts were mated each day they were detected in standing estrus. Only data from analyzed batches were included in the data analysis. Data were collected for three full years, starting with breeding dates during the fall of 2003 and ending in the summer of 2006.

\subsection{Internal laboratory quality control}

Extended, pooled semen doses were analyzed 2$4 \mathrm{~d}$ after collection, by an independent third-party lab- 
oratory (Swine Vet Center, P.A.). Samples were mixed using a magnetic stir plate, with pipetting commencing immediately for dilution of the sample. The diluted samples were then inverted four times, followed by vortexing for $10 \mathrm{~s}$, and then immediately loaded into a hemocytometer or into a Leja slide. Dose concentration was determined either by hemocytometer, following World Health Organization Procedures, or by computer assisted sperm analysis technology (CASA; Hamilton Thorne Ultimate, Hamilton Thorne Biosciences, Inc., Beverly, MA, USA). When done by CASA, samples were cross-referenced quarterly with two other labs as part of internal quality control and results followed predetermined standards by CIVAL (Consortium of Independent Veterinary Andrology Laboratories). Pipettes and scales were calibrated weekly using weights traceable to NIST (National Institute of Science and Technology) standards. On Days 2-5 after semen collection, bacteria were cultured using standardized methods. Positive culture results were further identified by the University of Minnesota Veterinary Diagnostic Laboratory (St. Paul, MN, USA).

\subsection{Data collected from the analysis laboratory}

Records collected from the analysis laboratory included: sperm counts (if multiple samples were submitted from the same batch, an average was used for the analysis), presence of bacteria, and genus of bacteria isolated.

\subsection{Data collected from farms}

Data were collected from each of the two farm systems using PigChamp swine software (Farms.com Ltd. Ames, IA, USA). Service number (servno, which is the number of service periods during a parity), number of inseminations per estrus (servnmates), parity, previous lactation length, and weaning to estrus interval (prevwean1stservint) data were collected and analyzed for potential confounding and interactions. Farrowing rate and total born were determined.

\subsection{Sperm count grouping}

To normalize the data distribution, actual sperm counts were grouped into ranges in increments of $0.5 \times 10^{9}$ sperm, starting with $<2.5 \times 10^{9}$ sperm, and ending with $>4.5 \times 10^{9}$ sperm.

\subsection{Statistical analysis}

All data were analyzed using GLIMMIX Procedures (SAS Institute, Inc., Cary, NC, USA). Data were analyzed for normal distribution. Data for total number of piglets born per litter were logarithmically transformed
Table 1. Effects of various factors on farrowing rate in swine $(n=9502$ records $)$

\begin{tabular}{lrrrr}
\hline Effect & d.f. & Chi-square & $F$ value & $\operatorname{Pr}>F$ \\
\hline Farm & 1 & 13.52 & 13.52 & 0.0002 \\
Season & 3 & 0.65 & 0.22 & 0.8838 \\
Service no. & 2 & 178.62 & 89.31 & 0.0001 \\
Season $\times$ service no. & 6 & 14.66 & 2.44 & 0.0231 \\
SMATES & 3 & 274.89 & 91.63 & 0.0001 \\
Sperm no. & 5 & 6.07 & 1.21 & 0.2998 \\
Season $\times$ sperm no. & 15 & 12.12 & 0.81 & 0.6701 \\
Bacteria & 1 & 2.12 & 0.15 & 0.1457 \\
Farm $\times$ bacteria & 1 & 4.25 & 0.04 & 0.0393 \\
Season $\times$ bacteria & 3 & 6.71 & 0.08 & 0.0818 \\
Sperm no. $\times$ bacteria & 5 & 8.64 & 0.12 & 0.1246 \\
\hline
\end{tabular}

before performing ANOVA. Nonsignificant interactions $(P>0.05)$ were removed from the final model. The statistical difference in farrowing rate data was determined by chi-square. The significance level was set at $P \leq 0.05$, whereas trends were noted at $P \leq 0.10$.

\section{Results}

\subsection{Farrowing rate}

As expected, farrowing rate decreased significantly as the number of inseminations decreased (servnmates) and the number of service periods (servno) increased. There was no significant difference associated with parity, previous lactation length, previous wean to first service interval, or season (Table 1). There was no significant effect of bacteria nor interaction between sperm number and bacteria. There was no significant difference in farrowing rate for the various sperm count categories (Table 2).

\subsection{Total born}

The total born decreased significantly as the number of inseminations decreased (servnmates) and the number

Table 2. Effect of sperm number category on farrowing rate in swine $(P=0.29)$

\begin{tabular}{lrr}
\hline $\begin{array}{l}\text { Sperm no. } \\
\left(\times 10^{9} / \text { dose }\right)\end{array}$ & $\begin{array}{r}\text { No. of } \\
\text { inseminations }\end{array}$ & $\begin{array}{r}\text { Mean farrowing } \\
\text { rate }(\%)\end{array}$ \\
\hline$<2.5$ & 638 & 69.9 \\
$2.50-2.99$ & 1845 & 70.3 \\
$3.00-3.49$ & 3266 & 71.1 \\
$3.50-3.99$ & 2233 & 67.1 \\
$4.00-4.49$ & 1024 & 75.9 \\
4.5 and more & 496 & 81.2 \\
\hline
\end{tabular}


Table 3. Effects of various factors on total number of piglets born ( $n=7311$ observations)

\begin{tabular}{lrrc}
\hline Effect & d.f. & $F$ value & Probability \\
\hline Farm & 1 & 14.83 & 0.0001 \\
Season & 3 & 9.17 & 0.0001 \\
Farm $\times$ season & 3 & 3.45 & 0.0158 \\
Service number & 3 & 3.07 & 0.0266 \\
SMATES & 1 & 42.66 & 0.0001 \\
Farm $\times$ SMATES & 1 & 5.21 & 0.0225 \\
Sperm no. & 5 & 9.87 & 0.0001 \\
Farm $\times$ sperm no. & 5 & 2.46 & 0.0308 \\
Season $\times$ sperm no. & 15 & 0.70 & 0.7841 \\
Bacteria & 1 & 0.65 & 0.4185 \\
Season $\times$ bacteria & 3 & 2.44 & 0.0627 \\
Sperm no. $\times$ bacteria & 5 & 2.46 & 0.0310 \\
\hline
\end{tabular}

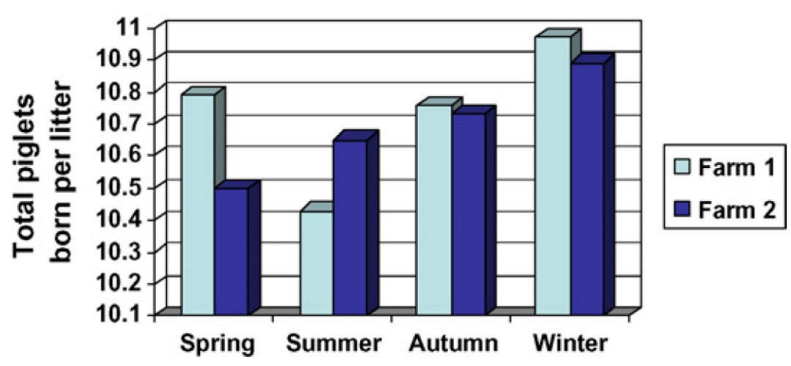

Figure 1. Effect of season and farm on total number of piglets born.

of service periods (servno) increased. There was no significant difference for parity, previous lactation length, or previous wean to first service interval (Table 3). There were no significant effects of bacteria nor significant interaction between sperm number and bacteria. There was a significant effect of season on total born, with an interaction by farm (Figures $1 \& 2$ ). Furthermore, there was a significant effect of sperm count category on total born, with a farm interaction.

\section{Discussion}

In previous work, there was a significant negative effect of insemination dose $\left(2 \times 10^{9}\right.$ compared to $3 \times 10^{9}$ sperm) on non-return rate and litter size in sows and gilts. ${ }^{1}$ In another study, there were decreased farrowing rates and litter sizes when using $0.5 \times 10^{9}$ sperm per dose compared to $4.0 \times 10^{9}$ sperm per dose using intrauterine insemination, or when using $4.0 \times 10^{9}$ sperm using conventional insemination. ${ }^{2}$ Finally, no significant difference was found using $1 \times 10^{9}$ compared to $3 \times 10^{9}$ sperm per dose with conventional insemination. ${ }^{3}$

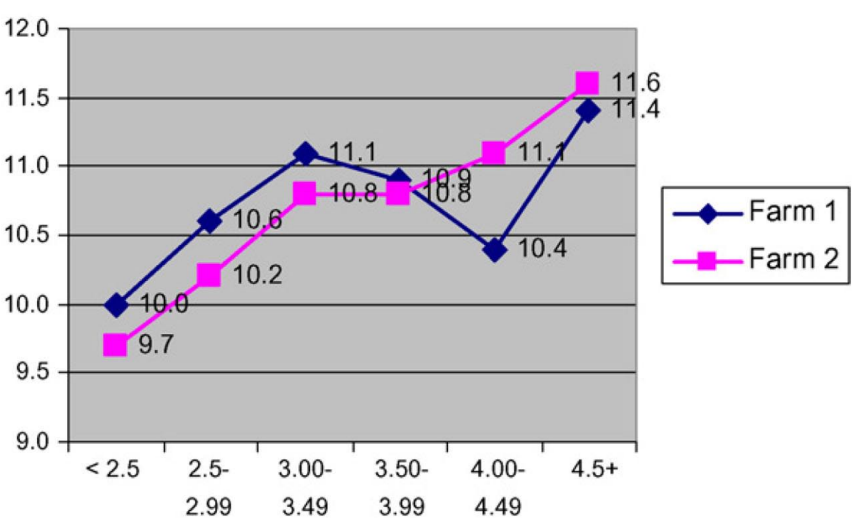

Figure 2. Effect of sperm number on total number of piglets born $(P=0.03)$, with an interaction by farm.

In the present study, there was no difference in farrowing rate among sperm count categories, but there was a significant difference in total born. In that regard, there was a large decrease in total born at sperm counts $<3.0 \times 10^{9}$ sperm/dose. A target above this range can be calculated, considering the boar studs' historical and current standard deviation on analyzed doses to determine the optimal setting. Both farm systems had their best total born when the sperm per dose was $>4.5 \times 10^{9}$ sperm.

Surprisingly, the presence of bacteria had no significance on either farrowing rate or total born. Individual genus and species of bacteria were determined; however, there were not enough data, and the data were not distributed well enough to derive conclusions regarding the importance of specific kinds of bacteria.

Considering the importance of genetic improvement, excessively high sperm counts would lead to the distribution of semen from boars with lower genetic value. Thus, a recommendation of (3.0-3.5) $\times 10^{9}$ sperm would seem to be the optimal sperm count range to ensure acceptable total born numbers, with a target above this set as determined by the expected standard deviation from dose to dose.

\section{References}

1 K. Alm, O. A. T. Peltoniemi, E. Koskinen and M. Andersson, Porcine field fertility with two different insemination doses and the effect of sperm morphology, Reprod Domest Anim 41 (2006), pp. 210-213.

2 K. J. Rozeboom, D. L. Reicks and M. E. Wilson, The reproductive performance and factors affecting on-farm application of low-dose intrauterine deposit of semen in sows, $J$ Anim Sci 82 (2004), pp. 2164-2168.

3 C. Krueger and D. Rath, Intrauterine insemination in sows with reduced sperm number, Reprod Fertil Dev 12 (2000), pp. 113-117. 